\title{
Seismic and volcanic activity during 2014 in the region involved by TOMO-ETNA seismic active experiment
}

\author{
Graziella Barberi ${ }^{1}$, Elisabetta Giampiccolo ${ }^{1}$, Carla Musumeci ${ }^{1,{ }^{\star}}$, Luciano Scarfi ${ }^{1}$, \\ Valentina Bruno $^{1}$, Ornella Cocina ${ }^{1}$, Alejandro Díaz-Moreno ${ }^{2}$, Simona Sicali $^{1}$, Giuseppina Tusa ${ }^{1}$, \\ Tiziana Tuvè ${ }^{1}$, Luciano Zuccarello ${ }^{1}$, Jesús M. Ibáñez ${ }^{1,2}$, Domenico Patanè ${ }^{1,2}$ \\ ${ }^{1}$ Istituto Nazionale di Geofisica e Vulcanologia, Sezione di Catania, Osservatorio Etneo, Catania, Italy \\ ${ }^{2}$ Instituto Andaluz de Geofisica, Universidad de Granada, Granada, Spain
}

\author{
Article history \\ Received February 5, 2016; accepted May 30, 2016. \\ Subject classification: \\ Sicily, Seismicity, TOMO-ETNA experiment, Volcanic activity.
}

\section{ABSTRACT}

This paper presents an overview of the seismic and volcanic activity occurred during 2014 in the region involved by the TOMO-ETNA seismic active experiment (Mt. Etna, Aeolian Islands and Peloritani-Messina Strait areas). To better characterize the seismicity over the year, threedimensional hypocenter locations and focal mechanism solutions of a dataset of 678 selected small-to-moderate magnitude earthquakes $\left(0.5 \leq \mathrm{M}_{\mathrm{L}} \leq 4.3\right)$ were analyzed. In the framework of the TOMO-ETNA experiment, a temporary seismic network was installed on-land from June to November 2014, both to acquire seismic signals produced by shots and to record the local seismicity. Data collected by the temporary network were used to integrate those deriving from the permanent seismic network operated by the Istituto Nazionale di Geofisica e Vulcanologia (INGV)Osservatorio Etneo, thus obtaining a numerically more robust dataset. In agreement with previous analysis and studies, the distribution of the hypocentral locations is well representative of the seismicity that typically characterizes this area. The selected well-constrained 42 fault plane solutions evidence two domains characterized by different motions and style of deformation. In particular, an extensional domain in the northeastern Sicily and a strike-slip regime in the northernmost part of the studied region have been observed.

\section{Introduction}

Sicily and Calabria (Figure 1a) lie at the boundary between the converging African and Eurasian plates, in a sector of the Mediterranean that is among the most seismically active regions and that has been affected by some earthquakes among the strongest occurred in Italian seismic history (up to intensity X-XI; Figure 1b). The eastern part of Sicily is also characterized by two active volcanic regions: Mt. Etna and the Aeolian Archipelago, located in central eastern Sicily and in the southern Tyrrhenian Sea, respectively (Figure 1a).
In particular, Mt. Etna stands at the front of the southeast-verging Apennine-Maghrebian fold-andthrust belt (Figure 1a), where the NNW-trending Malta Escarpment separates the Sicilian continental crust from the Ionian Mesozoic oceanic basin, presently subducting beneath the Calabrian arc [Selvaggi and Chiarabba 1995]. The complex geological history and tectonic setting of Mt. Etna have given rise to a great number of models to interpret its origin and the peculiar features for a very active basaltic volcano that is so unusually located in front of an active thrust belt [e.g. see Branca et al. 2011; Patanè et al. 2011].

Instead, the Aeolian Archipelago represents a volcanic arc made up of seven major islands (Figure 1c) and a wider seamount system, result of the Ionian lithosphere subduction beneath the Calabrian Arc [e.g. Barberi et al. 1994; Mantovani et al. 1996] and of a post-subduction extensional deformation [Beccaluva et al. 1985; Westaway 1993; Ventura et al. 1999; De Astis et al. 2003].

The tectonic structures characterizing the northern Sicily and its Tyrrhenian offshore are related to a very complex geodynamic context associated to both the collision between African and European plates and to the evolution of Tyrrhenian Basin. In particular, the recent deformation pattern of the Sicilian Maghrebides is interpreted as a result of brittle and brittle-ductile neotectonic structures with strike-slip kinematics developed since Middle-Late Miocene in the internal zones of the thrust belt, in turn related to the recent Tyrrhenian opening [Giunta et al. 2009]. The seismicity in the Sicilian Maghrebides is mainly located in the hinge zone between northern Sicily and southern Tyrrhenian, either crustal or deeper, and limited in two main 

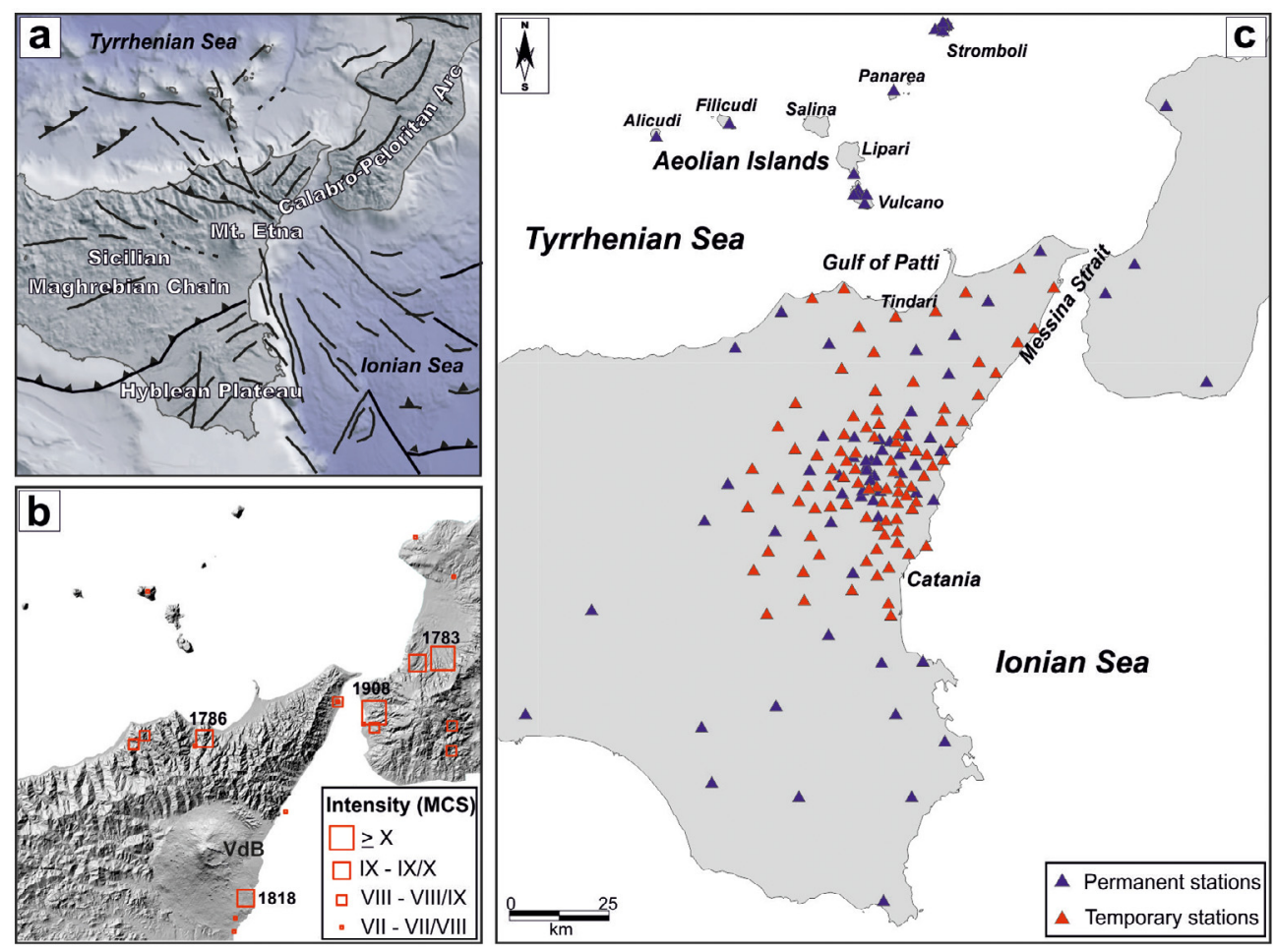

Figure 1. (a) Simplified tectonic map of Sicily and Calabria (after Musumeci et al. [2014]). (b) Strong historical events affecting northeastern Sicily and southern Calabria [Azzaro et al. 2008]. VdB = Valle del Bove. (c) Map distribution of the permanent and temporary seismic stations.

hypocentral sectors [Gueguen et al. 2002; Giunta et al. 2009]. Deep seismicity (up to about $230 \mathrm{~km}$ ), concentrated in the southern Tyrrhenian, is associated with the subduction of the Ionian lithospheric slab beneath the Calabrian arc, while shallow seismicity is the expression of the brittle strain crossing the whole orogeny [Neri et al. 1996]. The shallow seismicity of the southern Tyrrhenian Sea ( $<30 \mathrm{~km}$ deep) shows the occurrence of two adjacent compartments, which are characterized by different tectonic regimes: a N-S compression to the west of the Aeolian Islands, and a NW-SE extension to the east and southeast [Anderson and Jackson 1987; Neri et al. 2003; Montone et al. 2004; Pondrelli et al. 2004]. The transition zone between these compartments corresponds, at depths of about $100-200 \mathrm{~km}$, to the lateral (western) termination of the Ionian Wadati-Benioff zone [Piromallo and Morelli 2003; Faccenna et al. 2004, 2005] and, at shallow depths (i.e., $<30 \mathrm{~km}$ ), to the Tindari Fault System in the northern Sicily [e.g. Scarfi et al. 2016] and to the recent Aeolian volcanic edifices (i.e., Vulcano, Lipari and Salina).

Mt. Etna seismicity (volcano-tectonic earthquakes, VT hereafter) mainly occurs in the shallower crust (depth $<10 \mathrm{~km}$ ) with a high rate of earthquakes of low and moderate magnitude, which seldom exceed 4.0 [Patanè et al. 2004; Patanè and Giampiccolo 2004]. About three decades of detailed seismological studies on this volcano have shown that the distribution of VT seismicity in the intermediate and lower crusts (10-30 km) beneath Etna can be the key to infer the seismic response of local structures to the stress field induced from episodic ascent of magmatic batches from depth. The occurrence of intense seismic swarms at these depth levels, in the western and central-southern sectors of the volcano, has repeatedly been observed in the recent past and usually preceded the onset of volcanic activity [Bonaccorso et al. 1996; Vinciguerra et al. 2001; Patanè et al. 2004; Martínez-Arévalo et al. 2005; Alparone et al. 2012; Patanè et al. 2013; Sicali et al. 2015]. Mt. Etna earthquakes basically share their signatures with seismic events recorded in a tectonic environment, such as those occurring in the nearby areas of the Hyblean Plateau and Peloritani-Calabrian Arc [Patanè et al. 1997; Patanè and Giampiccolo 2004], generated by regional tectonic stresses and/or by local stresses deriving from magma migration in the Earth's crust and providing the necessary energy for rock failure.

Much still remains unclear about the relationship between seismicity and recognized faults, and between seismicity and volcanism, as well, especially when we look at a geodynamic context larger than the single volcano. It is worth stressing that the geodynamic setting of the complex southern Tyrrhenian - Calabrian Arc Ionian Basin is one of the most intriguing worldwide areas. In this framework, the TOMO-ETNA seismic active experiment might help to solve many shortcomings (for more details on the experiment, see in this volume: Cavallaro et al. [2016]; Coltelli et al. [2016]; Díaz-Moreno et al. [2016]; Firetto Carlino et al. [2016]; 
García et al. [2016]; Ibáñez et al. [2016a, 2016b]).

The experiment was carried out between June and November 2014, offshore of Etna and in the southern Tyrrhenian Sea, by applying both passive and active refraction/reflection seismic surveys and other geophysical investigations [Ibáñez et al. 2016a, in this volume]. It will allow investigating the structure of the crust beneath Mt. Etna, its offshore and under the Peloritani-Nebrodi chain, until the Aeolian Islands. This information could help to answer to the many issues still unresolved by exploiting the large amount of data acquired during the campaign and provided by the cutting-edge monitoring systems deployed in eastern Sicily, including Mt. Etna volcano.

Data collected by the temporary seismic stations installed in the framework of TOMO-ETNA experiment were used to integrate those deriving from the permanent seismic network operated by the Istituto Nazionale di Geofisica e Vulcanologia (INGV) - Osser- vatorio Etneo (hereafter, INGV-OE). We performed the 3D hypocentral location of a selected dataset of events, investigating their spatial and temporal distribution. Focal mechanisms of a subset of earthquakes were also computed.

\section{Mt. Etna}

\subsection{VT seismicity}

The seismicity associated with VT earthquakes has been quite modest in 2014, both in terms of number and energy released by the events. In particular, during this period, about 250 earthquakes with maximum magnitude of 3.3 have been located in the volcanic region. The map distribution of this seismicity, located with the 1D velocity model proposed for Etna area by Hirn et al. [1991] and modified by Patanè et al. [1994], is reported in Figure 2. Seismicity has been mainly located in the eastern flank of the volcano, with two most im-

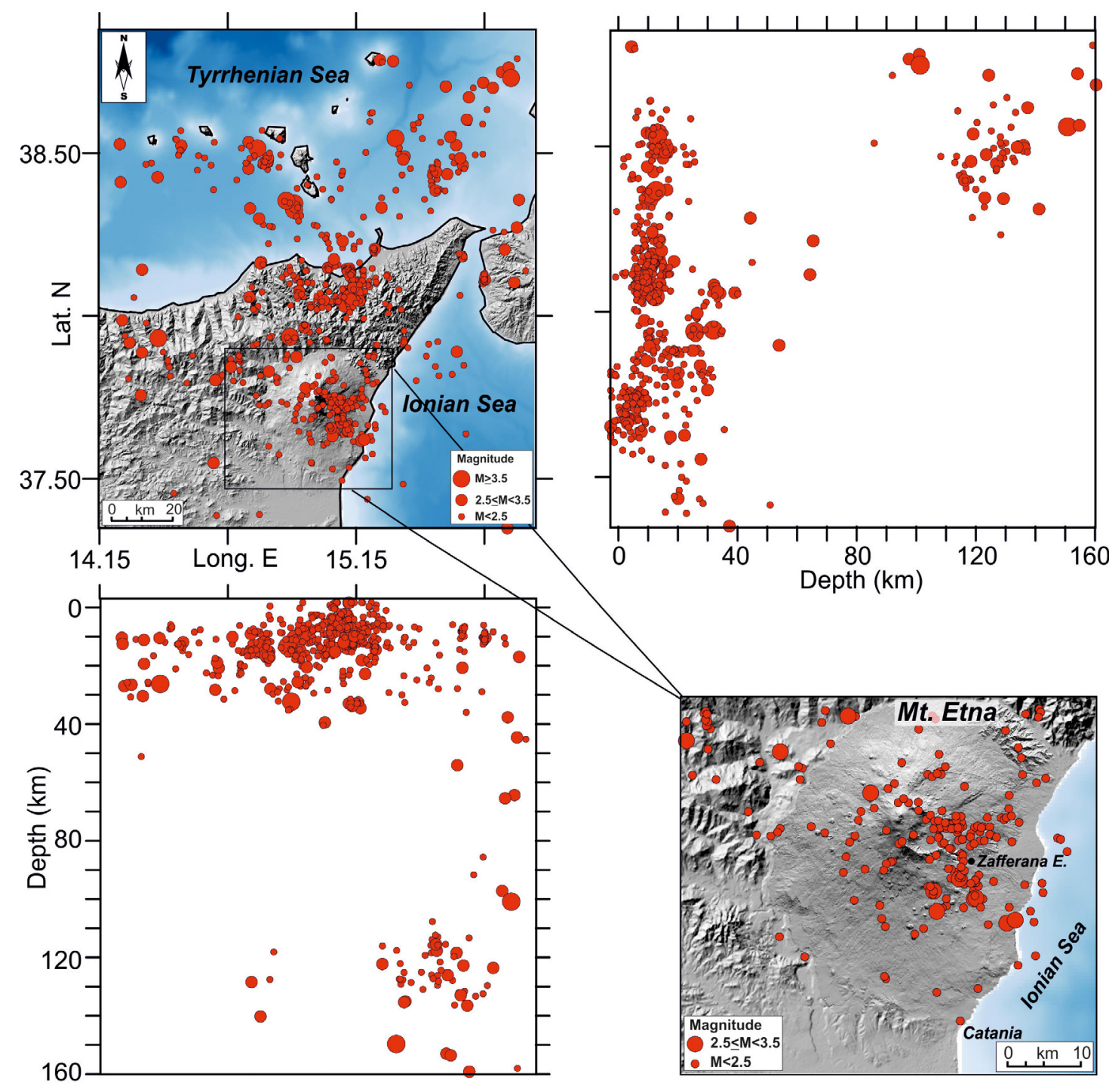

Figure 2. Epicentral maps and cross-sections of the $1 \mathrm{D}$ earthquake locations with depth $\leq 160 \mathrm{~km}$ recorded during 2014 in the study area [Gruppo Analisi Dati Sismici 2016]. At the bottom (right corner) a focus on Etna area is reported. 
portant seismic sequences occurred on March and September, both close to Zafferana Etnea village. The former, recorded on March 12, was characterized by 10 seismic events located at a depth ranging between 4 and $6 \mathrm{~km}$, with maximum magnitude $\mathrm{M}_{\mathrm{L}}=2.9$. The latter, occurred at the end of September, was characterized by 15 earthquakes (maximum $\mathrm{M}_{\mathrm{L}}=3.3$ ) located at a depth range $0-1.5 \mathrm{~km}$. Isolated low magnitude earthquakes have been also located in the northern and western flanks of the volcano at a depth range $15-30 \mathrm{~km}$. Focal depths of the earthquakes, occurred in both sectors of the volcano, in general, reflect the peculiarities of the background seismicity at Mt. Etna [Patanè et al. 2004].

Earthquakes daily rate and associated seismic strain release are reported in Figure 3a. The seismic energy (E) is computed using the relationship $\log _{10} \mathrm{E}=$ $9.9+1.9 \mathrm{M}-0.024 \mathrm{M}^{2}$ [Richter 1958]. Figure 3a allows to highlight the background seismicity and the most relevant seismic swarms occurred in the southeastern flank in March, and at the end of September.
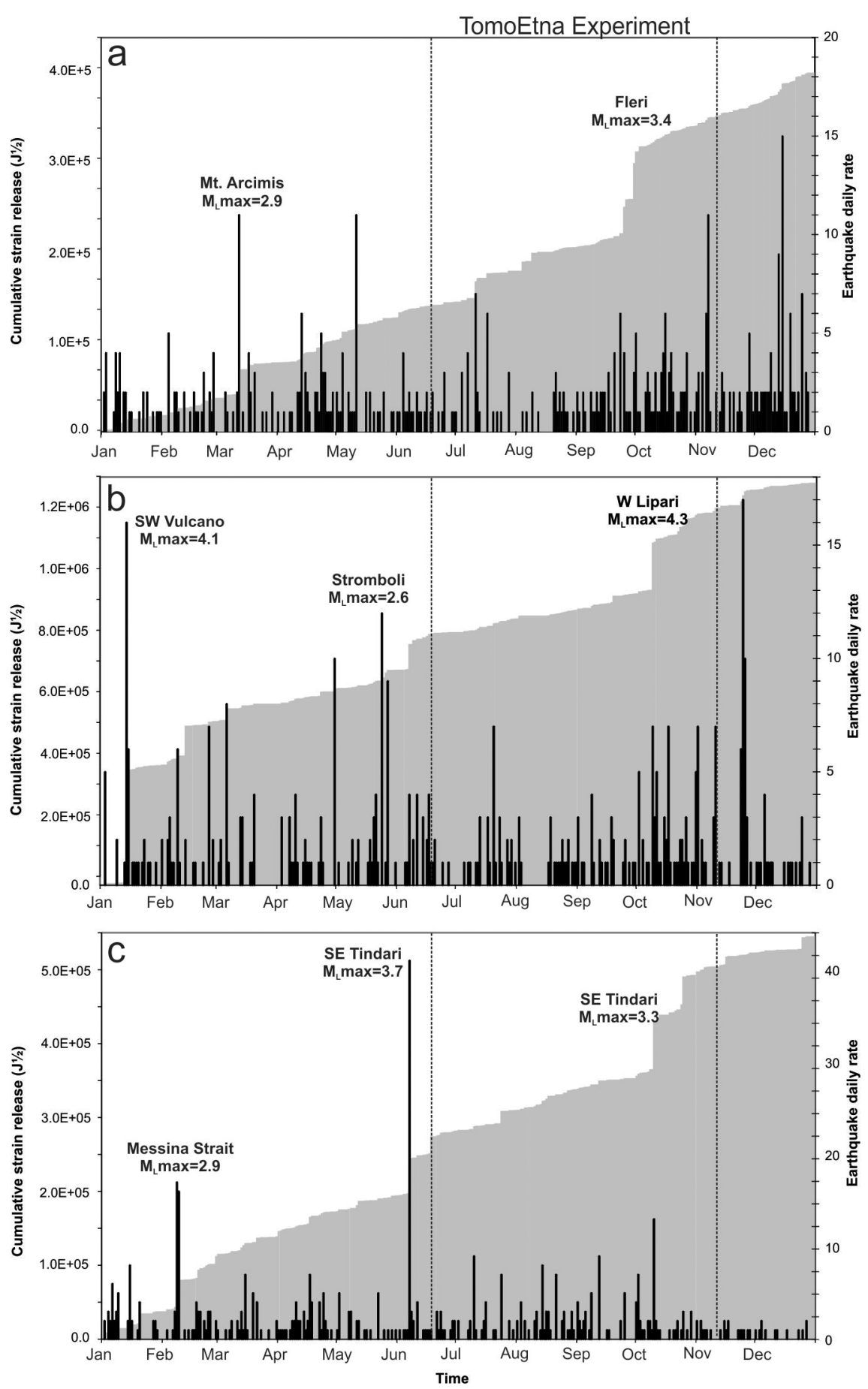

Figure 3. Earthquake occurrence and related cumulated strain release at Mt. Etna (a), Aeolian Islands (b) and Peloritani-Messina Strait area (c), during 2014. Dashed black lines delimit the time period during which the TOMO-ETNA experiment was carried out. 


\subsection{Volcanic activity}

During 2014, several episodes of volcanic activity characterized the volcano. Starting from the end of January, Strombolian activity has been observed at the New Southeast Crater (NSEC; see Figure 4a). This activity evolved quite slowly and it was limited to mild Strombolian activity at the summit of the cone, whereas lava was emitted from vents on its lower eastern flank (Figure 4a). It was rather different from the dynamics of the NSEC of the previous three years [De Beni et al. 2015], marking a transition from brief, violently explosive episodes to more long-lived, less explosive events, which characterized much of the eruptive activity during 2014 [De Beni et al. 2015]. This activity continued with fluctuations for 75 days, until the night of April 67 and it was followed by sporadic explosive activity at low energy. In the evening of June 14, NSEC woke up (Figure 4a,b). This eruptive episode which had been preceded by about five weeks of intermittent, weak Strombolian activity, lasted four days and it was characterized by intense Strombolian activity and lava emission, but no lava fountains and negligible tephra emission (Figure 4a).

After several weeks of relative quiescence, on July 5, mild Strombolian activity and slow lava emission (Figure 4a) started from two new vents located at 3000 $\mathrm{m}$ elevation on the lower east flank of the Northeast Crater (NEC), and from a further vent a short distance upslope, at $3090 \mathrm{~m}$ elevation, on July 25 [De Beni et al. 2015]. These vents were located about 700 and $600 \mathrm{~m}$ from the NSEC, respectively. There are several lines of evidence that this activity was fed by magma from the NSEC conduit, such as the formation of a system of dry fractures in the area between the new vents and the NSEC [De Beni et al. 2015]. The effusive activity continued until early August 10. In coincidence, Strombolian explosions increased in frequency and size at the
NSEC, heralding another eruptive episode. In the next months, new explosive episodes were recorded at NSEC in October and, after a relatively long break, on December 28 with a quite violent paroxysm. During the paroxysm, an eruptive fissure opened on the south side of the old cone of the South-East Crater (SEC), and emitted a lava flow reaching the altitude of $1900 \mathrm{~m}$ a.s.1 (Figure 4a).

The most outstanding event during 2014 was the collapse of a portion of the east flank of the cone on February 11, which led to the generation of an avalanche composed of rocks derived from the cone and hot lava derived from the active effusive vents that were incorporated in the collapse. This event, though similar in its characteristics to previous mass-wasting events in Etna's summit area [Calvari and Pinkerton 2002; Behncke et al. 2008; Norini et al. 2009] was of significantly larger proportions, presenting a previously underappreciated hazard [De Beni et al. 2015].

According to the areal variations calculated for two triangular sectors (see inset in Figure 5a), one related to three summit GPS stations (EPDN-EPLU-ECPN) and the other related to three intermediate altitude GPS stations (EMCN - ESLN - EMEG), we may identify the deformation patterns associated to the different volcanic phases of Mt. Etna. The ability to track inflation-deflation processes through areal variations or lengtheningshortening of GPS baselines at Mt. Etna has been already explored in Aloisi et al. [2011], Bruno et al. [2012] and Patanè et al. [2013]. In particular, during the analyzed period, three main ground deformation cycles, more evident on the summit part of the edifice, can be observed. The first one started in January, with a dilatation phase that culminated with the resume of Strombolian activity at the NSEC. Then, since February, an intense contraction accompanied the eruptive activity, involving the entire GPS network until Febru-
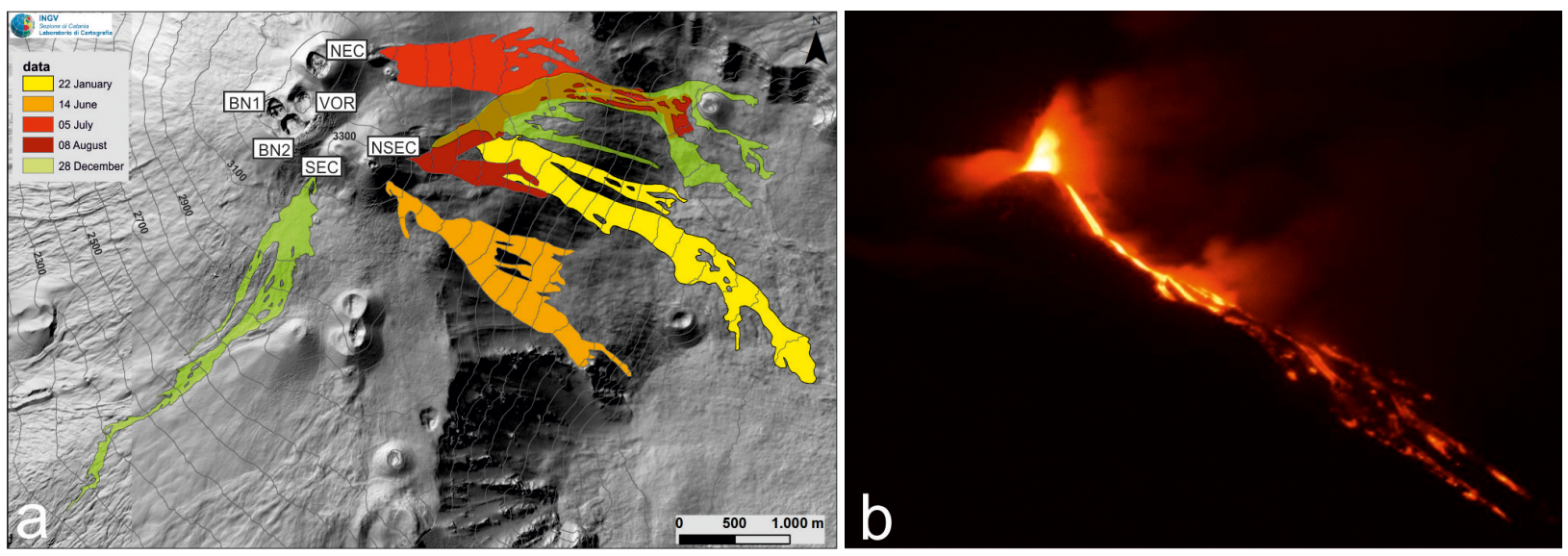

Figure 4. (a) Shaded relief images of Mt. Etna with the extent lava flow field that occurred during the 2014. NEC= North East Crater, $\mathrm{VOR}=$ Voragine, $\mathrm{BN}=$ Bocca Nuova, $\mathrm{SEC}=$ South East Crater and NSEC $=$ New South East Crater. (b) Eruptive activity at NSEC on June 15, 2014 (Ph Boris Behncke, INGV-OE). 

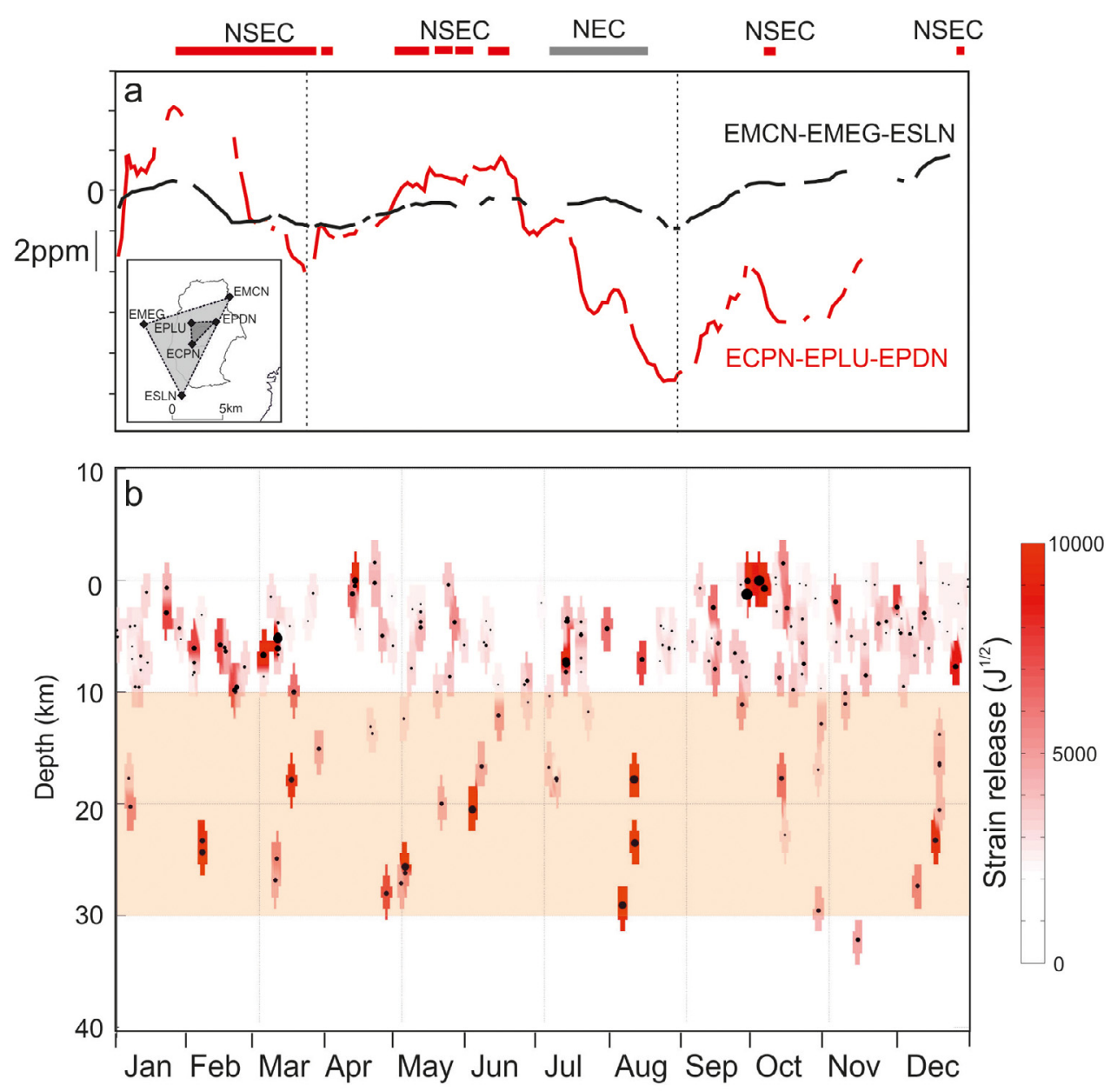

Figure 5. (a) Areal variations calculated for a summit (ECPN-EPLU-EPDN stations; red line) and an intermediate altitude triangle (EMCN ESLN-EMEG stations; black line). On the top, the red and gray horizontal bars show the eruptive activities occurred at NSEC and NEC, respectively. (b) Earthquakes depth with related strain release vs. time. The radius of the black dots is proportional to the magnitude. The orange band illuminates earthquakes located in the depth range 10-30 km.

ary 20. It was localized only to the summit area until March 22 when a new phase of areal variation started at the entire GPS network until June 15. After that, the stations located on the summit of the volcano edifice evidenced a new strong contraction, characterized by two minor cycles of dilatation-contraction: the first occurred just before the start of the eruptive activity on the vents opened at the base of the NEC and the second one during the eruption. At intermediate altitude, the contraction started on July 31 and ended on August 25 for the entire GPS network. In the period SeptemberDecember a new generalized phase of areal dilatation affected the entire volcanic edifice, clearly evidenced at all GPS stations. This variation preceded the renewal of the Strombolian activity started on October 7 at the NSEC and the intense paroxysm (lava fountain) occurred on December 28. This new paroxysmal took place after the last one of December 2, 2013.

In Figure $5 \mathrm{~b}$ we show the seismicity distribution in depth and relative seismic strain release of earthquakes during the investigated period. Several earthquakes in the intermediate-lower crust $(10<\mathrm{H}<30 \mathrm{~km})$ occurred before and during the eruptive cyclic phases of 2014. It is not the first time that relatively deep seismicity followed by variation/rejuvenation of volcanic activity has been observed. Indeed, intense seismic swarms during inter-eruptive periods, in the western and centralsouthern volcano's sectors, could anticipate the onset of volcanic activity [e.g. Bonaccorso et al. 1996; Patanè et al. 2004; Alparone et al. 2012; Patanè et al. 2013; Sicali et al. 2015]. Deep earthquakes probably occur when new magma enters the system from below and causes the pressure to increase. However, due to the few "deep" events recorded during 2014 and to their distribution spread all over the volcanic edifice, it is difficult to relate them to the periodic ascent of magma batches from depth. In contrast, the shallow earthquakes probably are due to a combination of factors which include magma potentially accumulated below $3 \mathrm{~km}$ and stress added to the system.

\subsection{Seismic signals associated with volcanic activity}

During the period under investigation, the most important eruptive events, occurred at NSEC and NEC, 


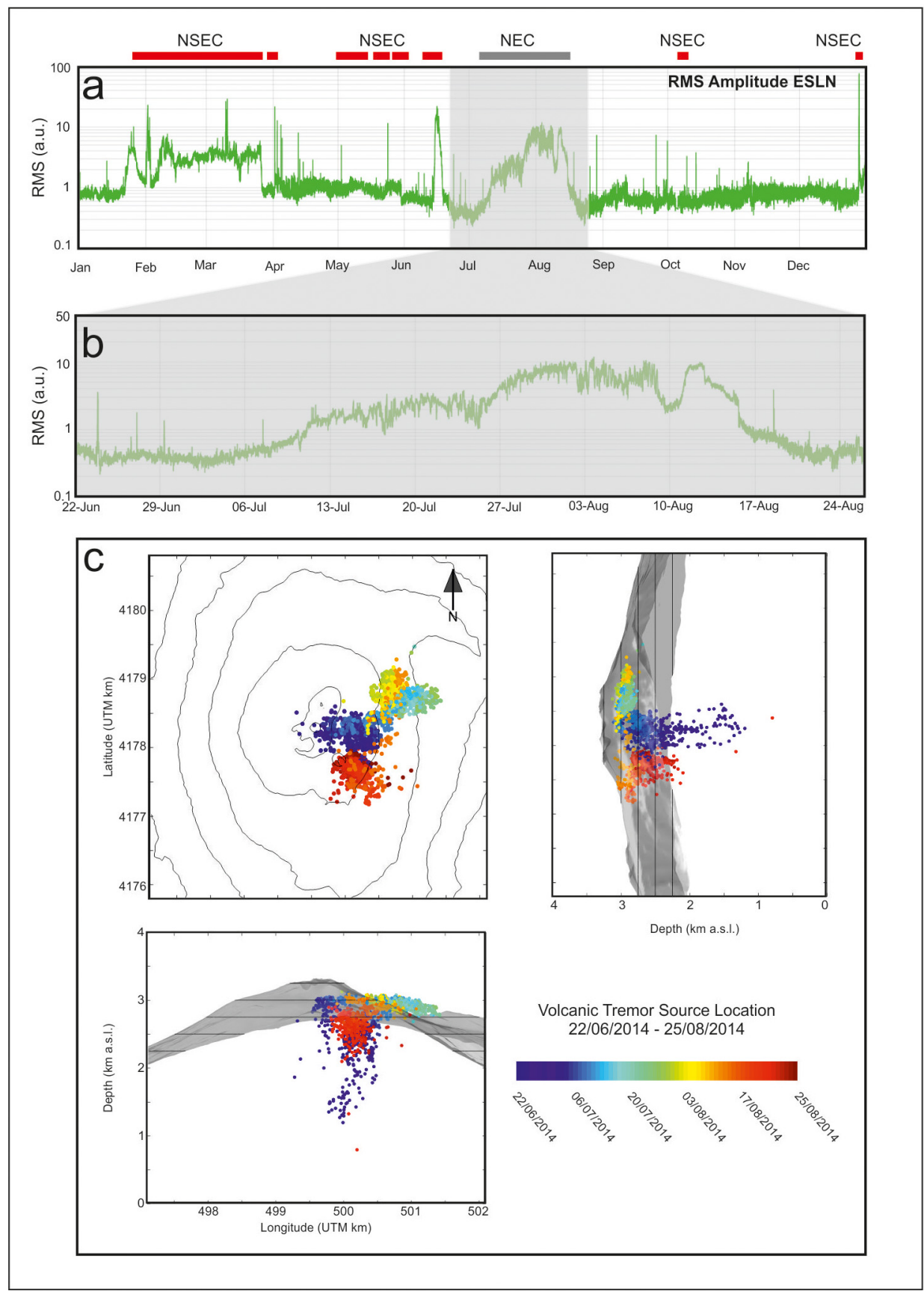

Figure 6. (a) Root-mean-square (RMS) tremor amplitude from the ESLN station during 2014. RMS is calculated over 10-minute-long sliding windows with $50 \%$ overlap in the $0.5-5.5 \mathrm{~Hz}$ frequency band. On the top, the red and gray horizontal bars show the eruptive activities occurred at NSEC and NEC, respectively. (b) Gray strip highlights the marked increase in the amplitude of the volcanic tremor observed during the 2014 eruption occurred at the flank of NEC. (c) Map and sections of Mt. Etna showing the spatial distribution of tremor source centroid locations during June 20 to August 25, 2014. Dots indicate the source position respect to the time evolution as illustrated by the color bar scale.

were accompanied by important variations of the volcanic tremor amplitude. Conversely, no important changes of recorded LP (long period) and VLP (very long period) signal were observed, in terms of both time variation and dominant frequency (INGV report at http://www.ct.ingvit).

In Figure 6a the temporal variation of the volcanic tremor amplitude during 2014 is shown. Most of the seismic radiation energy of the tremor is bounded between 0.5 and $5.5 \mathrm{~Hz}$, as reported by several authors [e.g. Cannata et al. 2013; Zuccarello et al. 2013] and as observed by a visual inspection of the seismograms recorded during 2014, as well. Therefore, the amplitude is here calculated as root-mean-square (RMS) over 10 min long time windows for the $0.5-5.5 \mathrm{~Hz}$ vertical-component signal from the seismic broadband station ESLN. In Figures $6 \mathrm{~b}$ and $6 \mathrm{c}$ the temporal and spatial variations in both amplitude and source centroid (evaluated every 30 min by using an amplitude-based method; e.g. Di Grazia et al. [2006, 2009]) of volcanic tremor during the June 20 - August 25, 2014, time interval are shown.

Several RMS amplitude features were observed 
during the study period: (i) high values of RMS tremor amplitude were recorded between January-March 2014, related to the NSEC eruptive activity; (ii) in late March the amplitude of the volcanic tremor has been decreasing until middle June, when the energy of seismic radiation increased abruptly, and the seismic tremor amplitude achieved high levels (Figure 6b); this particular RMS stage followed the entire eruptive fissure activity occurred on the eastern flank of NEC (Figure 6b); (iii) finally, high values of the tremor amplitude, associated with a powerful lava fountain, were recorded on December 28, 2014. On the basis of volcanic tremor source location (Figure 6c) three different source areas can be detected. In particular, before the eruptive fissure eruption, the tremor source spanned a volume with maximum length of about $2 \mathrm{~km}$ in depth, below the eastern flank of the Summit Craters; successively, during the eruptive period, the tremor source progressively began shallower with time, migrating towards the eruptive fissure (light blue - yellow colors in Figure 6c), at a very shallow depth ( $2.5-3.0 \mathrm{~km}$ a.s.1.). Finally, we observed a progressive repositioning of the tremor centroids towards the NSEC clustering at depths up to $\sim 1$ $\mathrm{km}$ beneath the surface (Figure $6 \mathrm{c}$ ).

\section{Aeolian Islands and Peloritani- Messina Strait area}

\subsection{Seismic activity}

During 2014, about 500 small-tomoderate magnitude earthquakes $\left(0.5 \leq \mathrm{M}_{\mathrm{L}} \leq 4.3\right)$ have been located at Aeolian Islands and in the PeloritaniMessina Strait area (Figure 1c). At the Aeolian Islands, seismic activity has been mainly recorded in the internal sector of the archipelago (Figure 2), to the south of Alicudi, Filicudi and Salina. The most energetic events, mainly ranging between 10 and $15 \mathrm{~km}$ depth, were recorded on January 14 (maximum $\left.\mathrm{M}_{\mathrm{L}}=4.1\right), 10 \mathrm{~km} \mathrm{SW}$ of Vulcano island, and on October 9 (maximum $\left.\mathrm{M}_{\mathrm{L}}=4.3\right), 12 \mathrm{~km} \mathrm{SW}$ of Salina.

A less energetic seismicity (only three VT earthquakes) were recorded near Stromboli at a depth of 5-7 km, with the maximum magnitude $\left(\mathrm{M}_{\mathrm{L}}=\right.$ 2.6) event occurred on May 26. Here the occurrence of VT earthquakes is not a usual feature being characterized by rare earthquakes of low magnitude [Falsaperla et al. 2003]. Finally, seismicity at Vulcano Island, usually related to fluid dynamics, was characterized by background levels of activity during the investigated time interval. In Figure $3 \mathrm{~b}$ earthquakes daily rate and associated seismic strain release in the Aeolian Islands area during the study period, are shown.

As regards northeastern Sicily region (including Messina Strait and southern Calabria; Figure 2), this was affected by a number of earthquake swarms, in some cases relevant both in number and energy released (Figure 3c). The first swarm occurred in the area of the Messina Strait at the beginning of February and it was characterized by earthquakes with maximum magnitude $M_{L}=2.9$. Two other swarms affected the area located southeast of Tindari (Figure 1c) in July (maximum $\mathrm{M}_{\mathrm{L}}=3.7$ ) and October (maximum $\mathrm{M}_{\mathrm{L}}=3.3$ ). Earthquakes depth, related to the above stated events, mainly ranges between 10 and $15 \mathrm{~km}$.
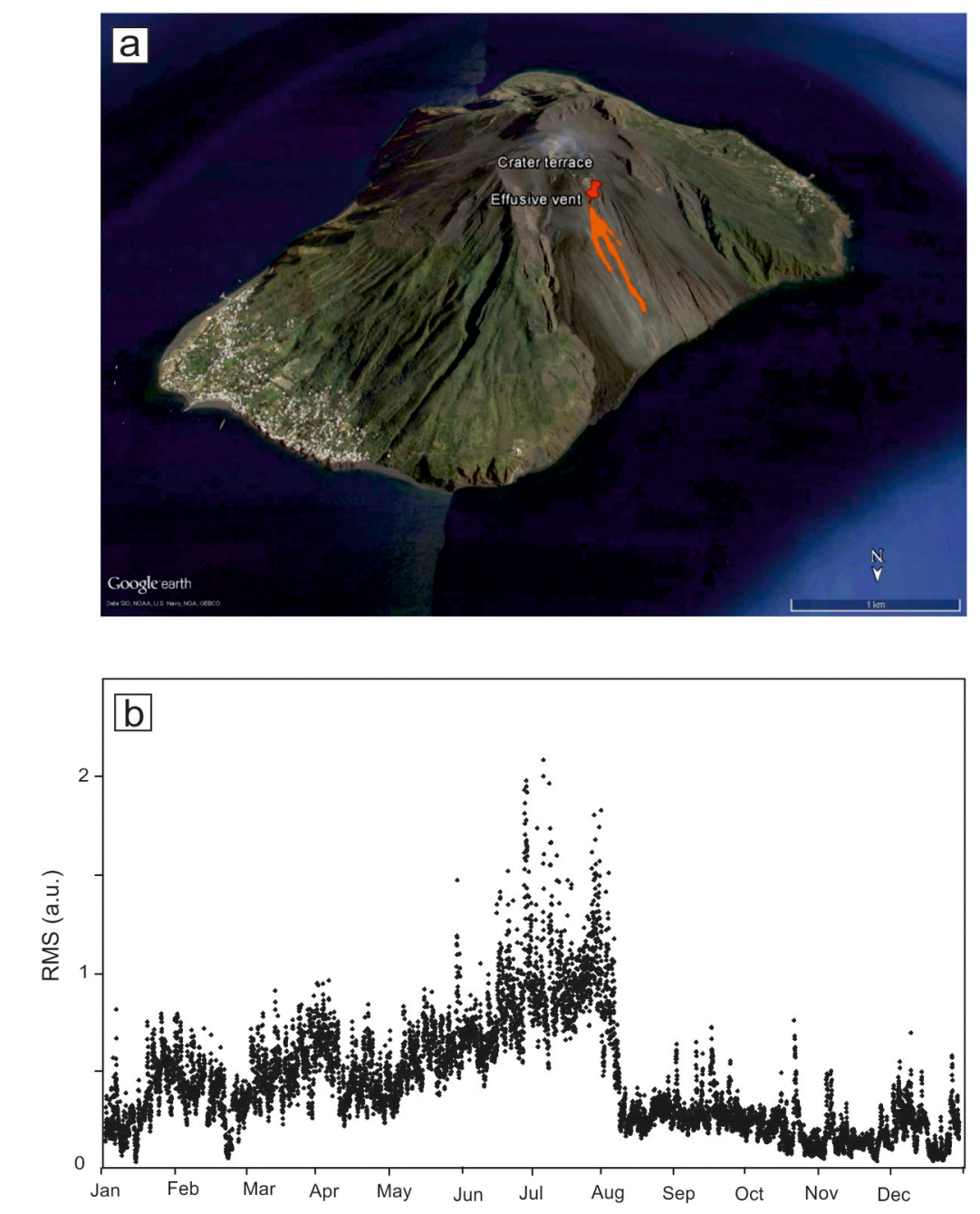

Figure 7. (a) Location of the lava flow on September 19, 2014, at Stromboli volcano. This is a perspective view from north to south (modified after Zakšek et al. [2015]). (b) Rootmean-square (RMS) tremor amplitude from the STR1 station, during 2014. RMS is calculated from spectra over 10-seconds-long windows (1024 points) with overlapping of 24 points in the $0.5-5.5 \mathrm{~Hz}$ frequency band. 


\subsection{Volcanic activity at Stromboli volcano}

After a period relatively quiet, in the early 2014 a marked increase in the Strombolian activity at Stromboli volcano was recorded. Several major and more energetic explosions occurred within a short time span, representing one of the most active periods during the year. Towards the end of May, volcanic activity at Stromboli increased as the magma level inside the conduit rose. The volcano had several small effusions until June when the increasing frequency of explosions and lava overflows led to the onset of an effusive eruption on August 6 (INGV report at http: / / www.ct.ingv.it) from a fracture located in the external part of the northeast crater.

On August 7, at 5:15 GMT, a new fracture with lava flow opened at $650 \mathrm{~m}$ a.s.1., rapidly extending down the Sciara del Fuoco in several fronts (Figure 7a; Zakšek et al. [2015]). The activity was accompanied by numerous landslides (INGV report at http: / / www.ct. ingv.it). This was associated with the end of a persistent explosive activity from the craters. Then, the activity was characterized by a variable degassing rate and sporadic ash/lava explosions, with the exception of a more energetic explosion on October 18. The eruptive fracture and the lava flow remained approximately constant until October 28, when it reduced markedly. The effusion rate subsequently remained at a very low level until November 13-17, when the effusion ceased [Rizzo et al. 2015].

3.3. Seismic signals associated with volcanic activity at Stromboli volcano

A good correspondence is found between volcanic activity and variation in tremor amplitude at Stromboli volcano. In particular, the volcanic tremor amplitude level remained low until May. Then it increased until the effusive eruption occurred on August (Figure $7 \mathrm{~b}$ ). Afterwards the amplitude showed a rapid diminution and quickly returned to background levels. As regards the VLP seismicity, a low-medium occurrence rate has been estimated between January and May. Successively, a slight increasing trend was observed, reaching its maximum in June. A further increase of the number of VLP events was recorded during the eruptive period, at the end of which it returned to the background level exhibited before the eruption. Even the frequency and polarization parameters of the VLP during the eruptive period exhibited some variations (INGV report at http: / / www.ct.ingv.it).

In general, the lack of strong geophysical signals preceding volcanic activity can be related to the low energy involved in magma upraise mechanisms. The low energy may be due to the small quantities of magma periodically injected in the shallow magma chamber, located above the sea level inside the volcano edifice [e.g. Patanè et al. 2007].

\section{3D locations and focal mechanisms in the region involved by TOMO-ETNA seismic active experiment}

The permanent seismic network, managed by INGV-OE, consists of 70 stations equipped with broadband (BB, hereafter) three-component seismometers (Figure 1c). All the important improvements over time have made possible to increase the ability to detect the seismicity, allowing recording and locating even low energy events.

From June to November 2014, 17 BB temporary stations, provided by the GFZ-Potsdam and operating in continuous mode, were installed at Mt. Etna in the framework of the TOMO-ETNA experiment. The BB stations (see Ibáñez et al. [2016a, 2016b] in this volume, for more details) were equipped with Trillium Compact 120s BB Seismometers and Earth Data Loggers (PR624). In addition, from June 26 to July 24,80 cube short period seismic stations, equipped with $3 \mathrm{D}$ Geophone PE-6/B and Mark 3DL4C sensors with DSS recorded system, worked simultaneously with the BB temporary and permanent stations, leading to a total of 167 seismic stations (see Figure 1c).

This enhanced monitoring system (temporary and permanent stations) allowed to re-analysing about 750 earthquakes located during 2014 in the study area (latitude N 37.35 - 38.85 and longitude E 14.20-15.80). Finally, 678 seismic events, with at least $8 \mathrm{P}$ - and S-phases observations, $\mathrm{GAP} \leq 280^{\circ}$ and location errors ERH and ERZ $\leq 4 \mathrm{~km}$, have been selected (http: / / www.ct.ingv. it/ufs/analisti / catalogolist.php; Gruppo Analisi Dati Sismici [2016]) and relocated by using the tomoDDPS code [Zhang et al. 2009] and the 3D velocity model by Scarfi et al. [2016]. Maps of the 678 final locations are shown in Figure 8a,b. Events are affected by uncertainty less than $0.3 \mathrm{~km}$ in the hypocentral coordinates and root-mean-square (RMS) travel-time residual less than $0.2 \mathrm{~s}$. Higher depth errors are mainly observed for the events occurring along the coastal sector of the study area because of the largest azimuthal gaps.

As shown in Figure 8a,b, the seismic events distribution is relatively well representative of the seismicity of the different areas. In particular, seismogenic depth varies from few kilometres to $30 \mathrm{~km}$ for Etna volcano (Figure $8 \mathrm{a}$ ), and from $8 \mathrm{~km}$ to $15 \mathrm{~km}$ for the Aeolian Islands (Figure $8 \mathrm{~b}$ ). In the Peloritani-Messina Strait area seismicity is mainly ranging between $5 \mathrm{~km}$ and $20 \mathrm{~km}$ (Figure 8b). Earthquakes deeper than $50 \mathrm{~km}$ are located beneath the Tyrrhenian Sea, with depth increasing steeply to about $200 \mathrm{~km}$. 

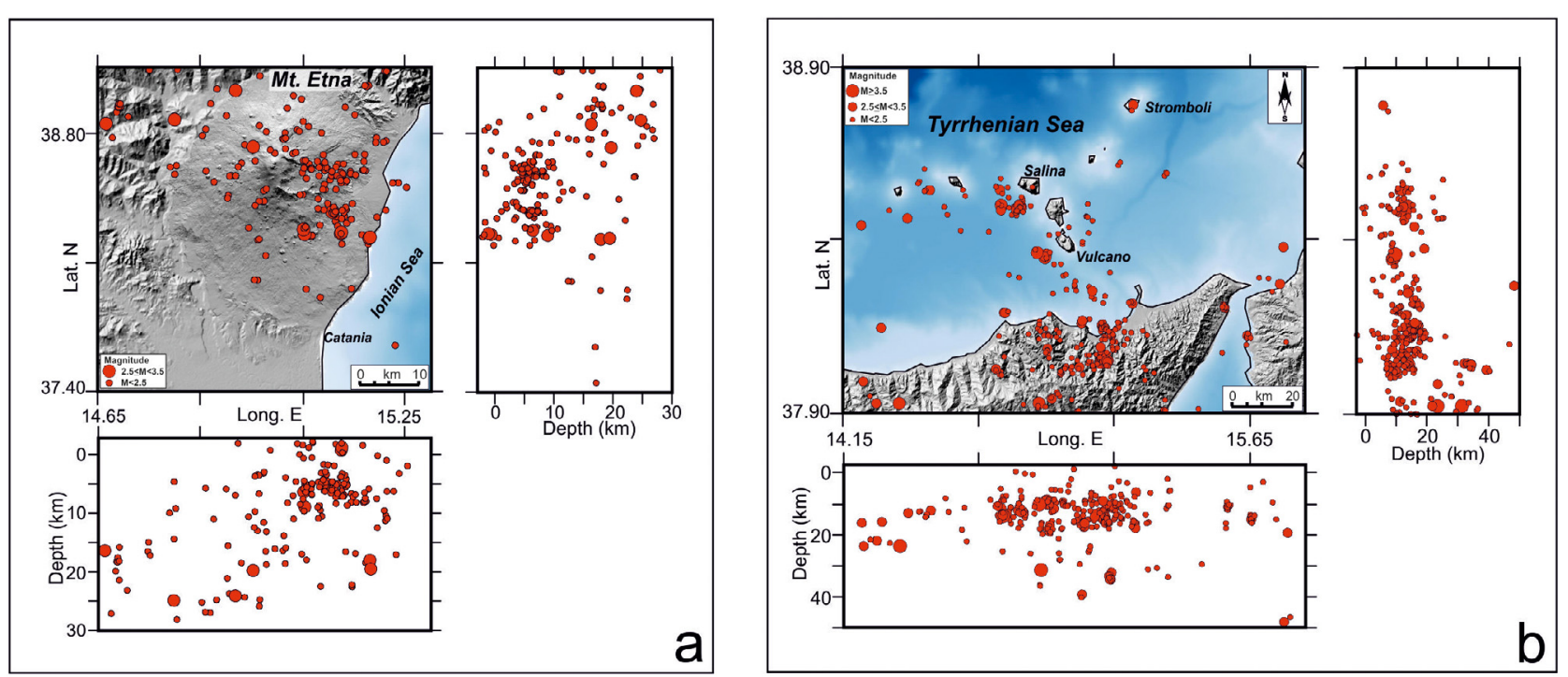

Figure 8. 3D location of earthquakes with depth $\leq 50 \mathrm{~km}$ for (a) Mt. Etna and (b) Aeolian Islands and Peloritani-Messina Straits areas.

To describe the kinematic behavior of the studied region, we computed focal mechanisms for the best recorded events by using the ray tracing obtained in the $3 \mathrm{D}$ velocity model. We applied the FPFIT program [Reasenberg and Oppenheimer 1985], which is a simple and conventional method using P-wave polarity data and their spatial distribution on the focal sphere. Most of the polarities were extracted from the Sicily and southern Calabria focal mechanism database (http: / / sismoweb.ct.ingv.it/focal/; see Scarfi et al. [2013]) which contains solutions for earthquakes with $M_{L} \geq 2.7$. This magnitude value can be considered a cautious threshold to achieve well-constrained fault plane solutions (FPSs) based on the permanent network configuration and the resulting available polarities. Data integration by the temporary $\mathrm{BB}$ stations allowed us to increase the polarities dataset. Moreover, when BB and cube short periods stations worked simultaneously, the increased number of polarities allowed us to obtain more stable FPSs for three events, two of which with magnitude $\mathrm{M}_{\mathrm{L}}<2.7$. The comparison (with and without integrated data, see Figure 9) of the polarity distribution on the focal sphere and of the associated uncertainties clearly indicates the improvement in the determination of the focal parameters. For these integrated FPSs, the errors associated to nodal planes range between $3^{\circ}$ and $10^{\circ}$, which are significantly low if compared with those obtained with permanent station polarities only $\left(10^{\circ}-20^{\circ}\right)$. In total we calculated 42 well constrained FPSs (Figure 10; Table 1).

In the whole area, rupture mechanisms show prevalently normal dip slip and strike slip movements (65\% are normal faulting and $35 \%$ strike slip ones). For each earthquake the projection of $\mathrm{P}$ - and T-directions, representative of the local maximum and minimum principal strain axis, is shown as inset in Figure 10. In particular, the horizontal projection of $\mathrm{P}$ axes is distributed along a NW-SE direction, showing a variation in plunge from sub-horizontal to vertical. T-axes are variously oriented with an average trend that is nearly horizontal. Although some horizontal compressive Paxes are observed, they are less numerous in comparison to the vertical ones, confirming that normal faulting mechanism prevails.

At the northernmost part of the studied area, where the majority of FPSs falls, two seismotectonic domains are clearly distinct. The first is characterized by steep P-axes and horizontal T-axes which reveal a dominant extensional regime (northeastern Sicily and southern Calabria). The second one, showing a strike-slip kinematics, is observed between the northern coast of Sicily and the Aeolian Islands (Figure 10).

\section{Conclusive remarks}

This paper is mainly devoted to describe the seismic and volcanic activity in the region involved by TOMOETNA seismic active experiment during 2014. The study area includes the Mt. Etna volcano, and northeastern Sicily with the Aeolian Archipelago, as well.

We discuss the results of a comprehensive study of the VT seismicity occurred in the study region which takes advantage of the installation of $17 \mathrm{BB}$ and 80 cube short period temporary stations in the framework of the TOMO-ETNA seismic active experiment.

The 3D earthquake locations (Figure 8) evidenced several zones of clustered seismicity with seismogenic depth ranging from few kilometers to $30 \mathrm{~km}$ for $\mathrm{Mt}$. Etna volcano and from 8 to $15 \mathrm{~km}$ for the Aeolian Islands. In the Peloritani-Messina Strait area seismicity is mainly ranging between $5 \mathrm{~km}$ and $20 \mathrm{~km}$. Earthquakes deeper than $50 \mathrm{~km}$ are located beneath the Tyrrhenian Sea, with depth increasing steeply to about $200 \mathrm{~km}$. 


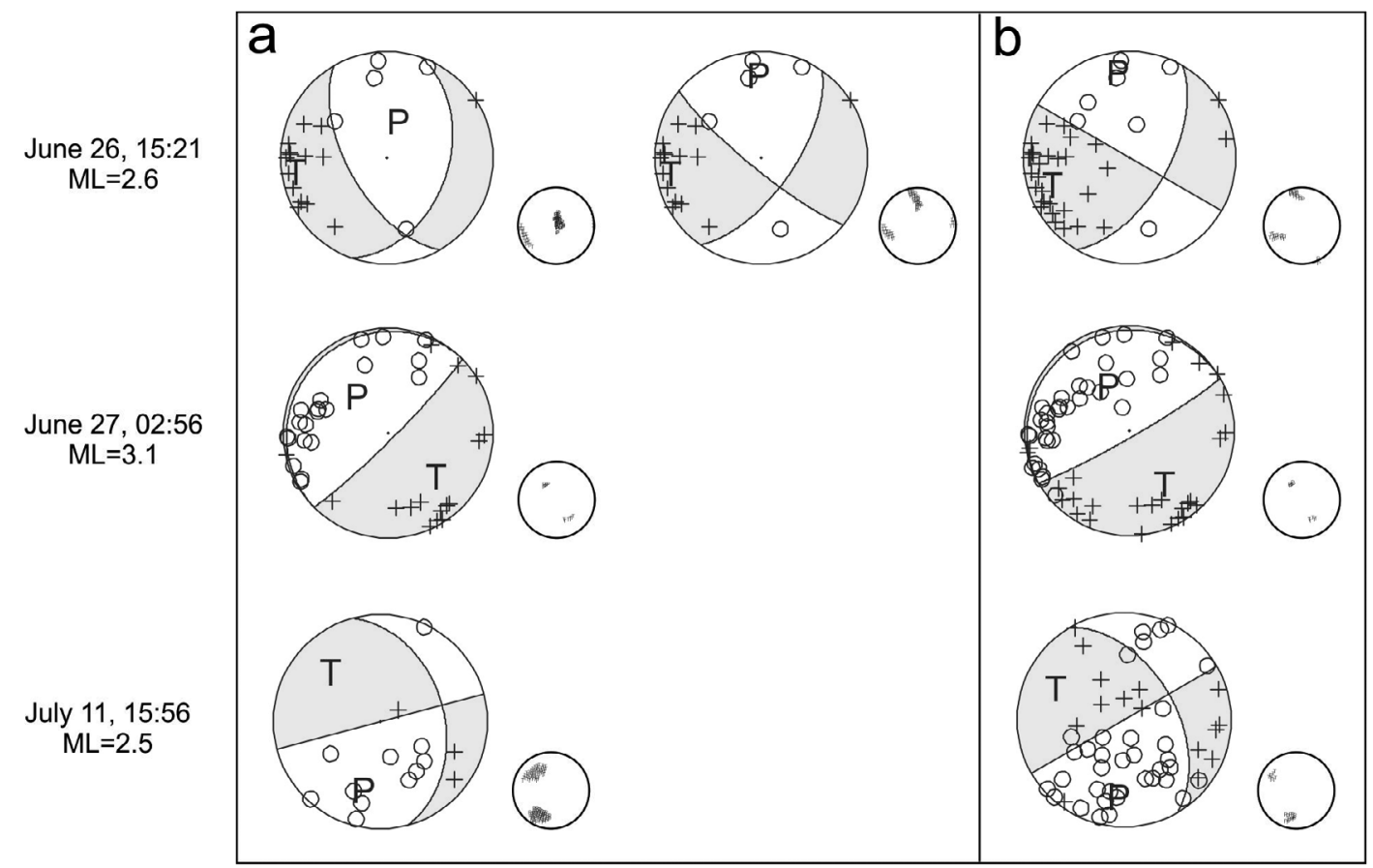

Figure 9. Comparison between focal mechanisms of three events obtained by using (a) only permanent stations and (b) integrating with temporary BB and cube short period seismic stations. The small circle in the lower right corner of each FPS shows the range of orientations of $\mathrm{P}$ and $\mathrm{T}$ axes within the 90-percent confidence interval consistent with the data, allowing for the uncertainty.

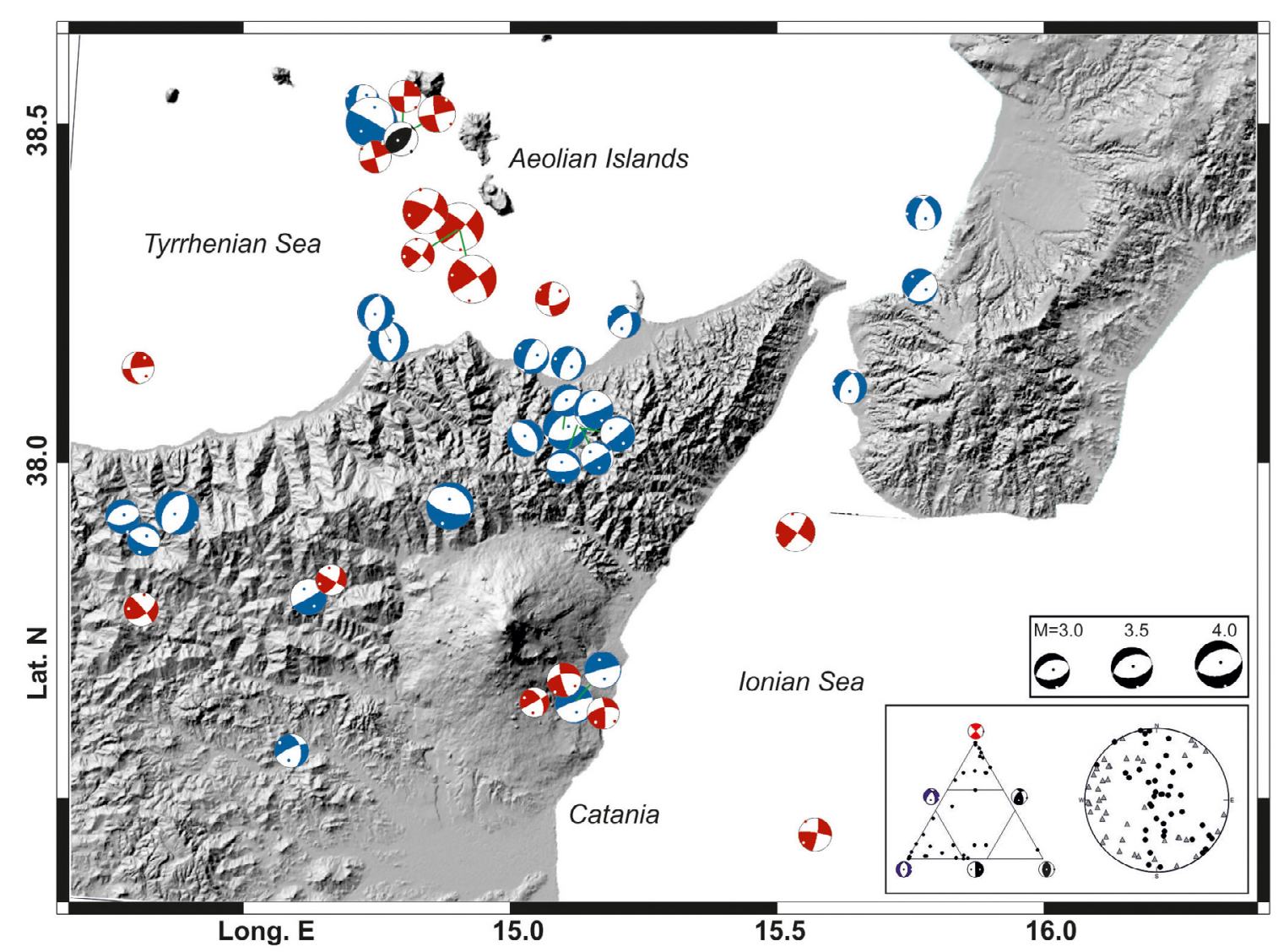

Figure 10. Map of the selected focal solutions computed in a 3D velocity model. The inset at the bottom right shows the triangular diagram of focal mechanisms (vertices represent normal, thrust, and strike-slip focal mechanisms; Frohlich [1992]). Plunges of P (circles) and T (triangles) axes (see inset) have been used to divide focal mechanism datasets into the main stress regime categories (blue = normal faulting; red = strike-slip; black= thrust faulting), according to the Zoback [1992] classification. 


\begin{tabular}{|c|c|c|c|c|c|c|c|c|c|c|c|c|c|c|c|c|c|}
\hline \multirow{2}{*}{$\begin{array}{c}\text { Date } \\
\text { yymmdd }\end{array}$} & \multirow[t]{2}{*}{ hh:mm } & \multirow[t]{2}{*}{ SS.SS } & \multirow[t]{2}{*}{ Lat. $N^{\circ}$} & \multirow[t]{2}{*}{ Lon. $E^{\circ}$} & \multirow[t]{2}{*}{$\mathrm{H}(\mathbf{k m})$} & \multirow[t]{2}{*}{$\mathbf{M}_{\mathrm{L}}$} & \multirow[t]{2}{*}{ N.P. } & \multicolumn{3}{|c|}{ PLANE1 } & \multicolumn{3}{|c|}{ PLANE2 } & \multicolumn{2}{|c|}{ P-AXIS } & \multicolumn{2}{|c|}{ T-AXIS } \\
\hline & & & & & & & & Strike & Dip & Rake & Strike & Dip & Rake & $\mathrm{Az}$ & $\mathrm{Pl}$ & $\mathrm{Az}$ & $\mathrm{Pl}$ \\
\hline 140102 & $06: 13$ & 17.79 & 38.1570 & 15.0395 & 15.42 & 3.0 & 18 & 65 & 30 & -50 & 201 & 67 & -110 & 79 & 62 & 306 & 20 \\
\hline 140113 & 18:01 & 13.80 & 37.7820 & 14.3087 & 30.17 & 2.9 & 40 & 55 & 60 & 10 & 320 & 81 & 150 & 11 & 14 & 273 & 27 \\
\hline 140114 & $03: 43$ & 42.03 & 38.3487 & 14.9047 & 11.37 & 4.1 & 47 & 45 & 80 & 20 & 311 & 70 & 169 & 177 & 7 & 270 & 21 \\
\hline 140114 & $04: 35$ & 0.49 & 38.3430 & 14.9063 & 10.9 & 4.1 & 47 & 55 & 85 & 20 & 323 & 70 & 175 & 187 & 10 & 281 & 18 \\
\hline 140120 & $22: 45$ & 12.82 & 37.8972 & 15.5340 & 54.15 & 3.3 & 31 & 305 & 90 & 170 & 35 & 80 & 0 & 350 & 7 & 260 & 7 \\
\hline 140208 & $18: 15$ & 32.88 & 38.1117 & 15.6360 & 12.13 & 2.9 & 17 & 350 & 45 & -120 & 209 & 52 & -63 & 181 & 69 & 281 & 4 \\
\hline 140219 & $06: 58$ & 5.11 & 38.1468 & 15.1087 & 14.03 & 2.9 & 23 & 5 & 25 & -110 & 207 & 67 & -81 & 134 & 67 & 290 & 21 \\
\hline 140228 & 02:39 & 37.99 & 38.3443 & 14.9018 & 10.25 & 2.8 & 13 & 40 & 75 & 10 & 307 & 80 & 165 & 354 & 4 & 263 & 18 \\
\hline 140306 & $16: 00$ & 19.93 & 38.3692 & 15.7745 & 20.41 & 3.0 & 17 & 330 & 45 & -130 & 200 & 57 & -57 & 164 & 62 & 267 & 7 \\
\hline 140307 & $12: 03$ & 24.89 & 38.3575 & 14.8767 & 12.15 & 3.8 & 21 & 35 & 70 & 20 & 298 & 71 & 159 & 347 & 1 & 256 & 28 \\
\hline 140308 & $20: 52$ & 50.90 & 37.9358 & 14.8872 & 31.99 & 4.0 & 52 & 105 & 65 & -100 & 308 & 27 & -70 & 355 & 68 & 202 & 19 \\
\hline 140312 & $00: 55$ & 38.09 & 37.6768 & 15.1005 & 5.76 & 2.9 & 46 & 165 & 80 & -30 & 261 & 61 & -168 & 119 & 28 & 216 & 13 \\
\hline 140314 & $03: 32$ & 23.43 & 38.1787 & 14.7718 & 13.86 & 3.4 & 21 & 5 & 40 & -80 & 172 & 51 & -98 & 38 & 82 & 268 & 5 \\
\hline 140314 & $03: 37$ & 15.68 & 38.1780 & 14.7757 & 13.35 & 3.1 & 19 & 5 & 50 & -100 & 200 & 41 & -78 & 222 & 81 & 102 & 5 \\
\hline 140411 & $05: 43$ & 5.10 & 38.1402 & 14.3033 & 17.16 & 2.7 & 17 & 175 & 50 & 0 & 85 & 90 & 140 & 138 & 27 & 32 & 27 \\
\hline 140417 & $21: 52$ & 25.92 & 38.2088 & 15.2132 & 15.45 & 2.8 & 27 & 355 & 50 & -140 & 237 & 61 & -48 & 200 & 53 & 298 & 6 \\
\hline 140423 & $20: 35$ & 56.24 & 38.5328 & 14.7235 & 13.68 & 2.9 & 8 & 55 & 50 & -40 & 173 & 61 & -132 & 30 & 53 & 292 & 6 \\
\hline 140517 & $22: 38$ & 44.32 & 37.4463 & 15.5710 & 25.18 & 2.8 & 42 & 10 & 80 & 10 & 278 & 80 & 170 & 324 & 0 & 234 & 14 \\
\hline 140607 & $15: 00$ & 48.11 & 38.0515 & 15.1025 & 13.22 & 3.7 & 54 & 75 & 45 & -70 & 228 & 48 & -109 & 68 & 76 & 331 & 2 \\
\hline 140607 & $15: 13$ & 19.18 & 38.0493 & 15.0990 & 13.18 & 2.7 & 39 & 55 & 50 & -90 & 235 & 40 & -90 & 325 & 85 & 145 & 5 \\
\hline 140626 & $15: 21$ & 48.65 & 37.8253 & 14.6645 & 18.28 & 2.6 & 37 & 300 & 90 & 150 & 30 & 60 & 0 & 349 & 21 & 251 & 21 \\
\hline 140627 & $02: 56$ & 48.06 & 37.8003 & 14.6217 & 18.28 & 3.1 & 60 & 60 & 85 & -90 & 240 & 5 & -90 & 330 & 50 & 150 & 40 \\
\hline 140711 & $15: 56$ & 31.84 & 37.6431 & 15.0452 & 8.68 & 2.5 & 51 & 60 & 90 & 40 & 330 & 50 & 180 & 187 & 27 & 293 & 27 \\
\hline 140724 & $01: 12$ & 50.36 & 38.0360 & 15.0280 & 38.74 & 3.1 & 45 & 135 & 50 & -100 & 330 & 41 & -78 & 352 & 81 & 232 & 5 \\
\hline 140809 & 07:07 & 1.23 & 37.6270 & 15.1740 & 18.8 & 2.7 & 47 & 355 & 80 & 30 & 259 & 61 & 168 & 124 & 13 & 221 & 28 \\
\hline 140826 & 01:19 & 45.37 & 37.9255 & 14.3757 & 25.14 & 3.7 & 53 & 20 & 50 & -100 & 215 & 41 & -78 & 237 & 81 & 117 & 5 \\
\hline 140826 & 03:02 & 54.66 & 37.9202 & 14.2740 & 24.9 & 2.9 & 39 & 80 & 50 & -80 & 245 & 41 & -102 & 43 & 81 & 163 & 5 \\
\hline 140906 & $16: 51$ & 31.15 & 37.8860 & 14.3130 & 20.14 & 2.8 & 26 & 115 & 65 & -80 & 272 & 27 & -110 & 45 & 68 & 198 & 19 \\
\hline 140919 & $05: 32$ & 37.71 & 38.4785 & 14.7945 & 14.65 & 2.9 & 17 & 35 & 50 & 70 & 245 & 44 & 112 & 139 & 3 & 240 & 74 \\
\hline 140925 & $16: 33$ & 57.65 & 37.6412 & 15.1207 & -1.19 & 3.3 & 34 & 40 & 10 & -120 & 250 & 81 & -85 & 166 & 53 & 336 & 36 \\
\hline 140930 & $23: 00$ & 55.92 & 37.6457 & 15.1238 & -1.72 & 3.1 & 24 & 25 & 5 & -140 & 255 & 87 & -86 & 169 & 48 & 341 & 42 \\
\hline 141009 & $22: 58$ & 26.44 & 38.5017 & 14.7400 & 16.53 & 4.3 & 50 & 300 & 85 & 110 & 43 & 21 & 14 & 12 & 37 & 231 & 46 \\
\hline 141010 & $16: 16$ & 18.22 & 38.0543 & 15.1353 & 32.09 & 3.3 & 46 & 70 & 80 & -70 & 186 & 22 & -153 & 3 & 51 & 143 & 32 \\
\hline 141010 & $16: 27$ & 13.08 & 38.0548 & 15.1253 & 32.44 & 2.9 & 37 & 85 & 65 & -100 & 288 & 27 & -70 & 335 & 68 & 182 & 19 \\
\hline 141010 & $16: 28$ & 12.80 & 38.0513 & 15.1300 & 33.26 & 3.0 & 33 & 50 & 85 & -100 & 294 & 11 & -27 & 309 & 49 & 149 & 39 \\
\hline 141010 & $17: 49$ & 33.98 & 38.0523 & 15.1315 & 34.06 & 2.8 & 35 & 60 & 90 & -110 & 330 & 20 & 0 & 311 & 42 & 169 & 42 \\
\hline 141022 & $15: 43$ & 7.40 & 37.5710 & 14.5902 & 25.31 & 2.9 & 22 & 350 & 45 & -160 & 246 & 76 & -47 & 196 & 42 & 305 & 19 \\
\hline 141022 & $22: 41$ & 51.92 & 38.4828 & 14.7938 & 15.15 & 3.1 & 15 & 80 & 90 & 170 & 170 & 80 & 0 & 125 & 7 & 35 & 7 \\
\hline 141026 & $00: 18$ & 46.64 & 38.4762 & 14.7877 & 14.53 & 2.7 & 13 & 75 & 85 & -180 & 345 & 90 & -5 & 300 & 4 & 30 & 4 \\
\hline 141026 & $23: 21$ & 58.30 & 38.4895 & 14.7982 & 15.35 & 2.7 & 16 & 180 & 85 & 0 & 90 & 90 & 175 & 135 & 4 & 45 & 4 \\
\hline 141105 & $16: 05$ & 48.64 & 38.2603 & 15.7675 & 46.56 & 3.0 & 10 & 85 & 20 & -50 & 223 & 75 & -103 & 115 & 58 & 324 & 29 \\
\hline 141116 & $12: 38$ & 41.63 & 38.2420 & 15.0788 & 11.98 & 2.9 & 22 & 80 & 60 & -20 & 180 & 73 & -148 & 44 & 34 & 308 & 8 \\
\hline
\end{tabular}

Table 1. Date, origin time, hypocentral parameters, magnitude, focal parameters of selected earthquakes. 
The occurrence of intermediate and deep earthquakes is related to the deflection of the subducting lithosphere towards the central Tyrrhenian basin [Anderson and Jackson 1987; Selvaggi and Chiarabba 1995; Cimini and Marchetti 2006].

Furthermore, the well-constrained 42 fault plane solutions (Figure 10) evidenced two domains characterized by different motions and style of deformation. In particular, a domain characterized by steep P-axes and horizontal T-axes reveals a dominant extension in the northeastern Sicily. In contrast, a strike-slip regime identifies the northernmost part of the studied region where horizontal P-axes, trending northwest direction, and horizontal T-axes, trending northeast, are observed.

The use of both temporary BB and cube short period stations, as integration to the existing permanent network data, provides a more uniform setting of the seismic stations, a more accurate determination of earthquake parameters and improved fault plane solutions for some earthquakes. On the basis of our results we retain that future analysis, devoted to the total integration of the seismic signals recorded at all the temporary seismic stations deployed during the experiment, will be very useful to better analyze the seismotectonic of the area through a more accurate characterization of the seismic source of the earthquakes. This is will be particularly useful for the easternmost area of Mt. Etna, around the coastline, because of the low station density of the present permanent network.

Acknowledgements. We wish to thank the Editor F. Bianco, the Associate Editor J. Morales, and the revision of Dr. M. Bretón and S. Alparone for their constructive comments. We are also grateful to A. Cannata and G. Di Grazia for the scientific support regarding seismic signals and E. De Beni for providing Etna lava flow field. This paper has been partially funded by the following research projects: the European project MED-SUV funded by the European Union's Seventh Framework Program for research, technological development and demonstration under grant agreement No. 308665; the Spanish COCSABO project (COC-DI-2011-08); the European project EUROFLEETS2 (Seventh Framework Programme, grant agreement No. 312762) through transnational access to the research vessels "Sarmiento de Gamboa" operated by CSIC (Spain) and "Aegaeo" by HCMR (Greece); the Geophysical Instrument Pool Potsdam (GIPP) from GFZ (Potsdam) with the project (Seismic TOMOgraphy of ETNA volcano and Eolian Islands, Italy, using active and passive seismic data). We would like to thank the following supporting institutions: Dipartimento Regionale della Protezione Civile, Regione Siciliana; Dipartimento Azienda Regionale Foreste Demaniali, Ufficio Provinciale di Catania; Ente Parco dell'Etna; Unidad de Tecnología Marina - CSIC in Barcelona (Spain); Stato Maggiore Marina (Italian Navy General Staff), CINCNAV (Command in Chief of the Fleet) and Marisicilia (Navy Command of Sicily); Coastal Guard of Messina and Riposto; to obtain support and navigation permissions for oceanographic cruises: Spanish Foreign Office and Italian Foreign Office. This paper has been partially supported by the Spanish projects TEC2015-68752-R (MINECO/ FEDER), KNOWAVES and CGL2015-67130-C2-2.

\section{References}

Aloisi, M., Mattia, M., Ferlito, C., Palano, M., Bruno, V., and F. Cannavò (2011). Imaging the multi-level magma reservoir at Mt. Etna volcano (Italy), Geophys. Res. Lett., 38, L16306, doi:10.1029/2011GL 048488.

Alparone, S., Barberi, G., Cocina, O., Giampiccolo, E., Musumeci, C., and D. Patanè (2012). Intrusive mechanism of the 2008-2009 Mt. Etna eruption: Constraints by tomographic images and stress tensor analysis, J. Volcanol. Geotherm. Res., 229-230, 50-63, doi:10.1016/j.jvolgeores.2012.04.001.

Anderson, H., and J. Jackson (1987). Active tectonics of the Adriatic Region, Geophys. J. Roy. Astr. S., 91, 937-983, doi:10.1111/j.1365-246X.1987.tb01675.x.

Azzaro, R., Barbano, M.S, D’Amico, S., Tuvè, T., Albarello, D., and V. D’Amico (2008). First studies of probabilistic seismic hazard assessment in the volcanic region of Mt. Etna (southern Italy) by means of macroseismic intensities, Boll. Geof. Teor. Appl., 49, 77-91, ISSN: 0006-6729.

Barberi, F., Gandino, A., Gioncada, A., La Torre, P., Sbrana, A., and C. Zenucchini (1994). The deep structure of the Eolian arc (Filicudi-Panarea-Vulcano sector) in light of gravity, magnetic and volcanological data, J. Volcanol. Geotherm. Res., 61, 189-206.

Beccaluva, L., Gabbianelli, G., Lucchini, F., Rossi, P.L., and C. Savelli (1985). Petrology and K/Ar ages of volcanic dredged from Eolian seamounts: implications for geodynamic evolution of the Southern Tyrrhenian basin, Earth Planet. Sci. Lett., 74, 187208.

Behncke, B., Calvari, S., Giammanco, S., Neri, M., and H. Pinkterton (2008). Pyroclastic density currents resulting from the interaction of basaltic magma with hydrothermally altered rock: an example from the 2006 summit eruptions of Mount Etna, Italy, B. Volcanol., 70, 1249-1268; http: / / dx.doi.org/10.100 7 / s00445-008-0200-7.

Bonaccorso, A., Ferrucci, F., Patanè, D., and L. Villari (1996). Fast deformation processes and eruptive activity at Mt. Etna (Italy), J. Geophys. Res., 101, 17467-17480.

Branca, S. Coltelli, M., and G. Groppelli (2011). Geological evolution of a complex basaltic stratovolcano: Mount Etna, Italy, Ital. J. Geosci. (Boll. Soc. Geol. It.), 130, 306-317.

Bruno, V., Mattia, M., Aloisi, M., Palano, M., Cannavò, F., and W.E. Holt (2012). Ground deformations and volcanic processes as imaged by CGPS data at Mt. Etna (Italy) between 2003 and 2008, J. Geophys. Res., 117, B07208, doi:10.1029/2011JB009114. 
Calvari, S., and H. Pinkerton (2002). Instabilities in the summit region of Mount Etna during the 1999 eruption, B. Volcanol., 63, 526-535; http: / / dx.doi. org/10.1007/ s00445010017.

Cannata, A., Di Grazia, G., Aliotta, M., Cassisi C., Montalto P., and D. Patanè (2013). Monitoring seismovolcanic and infrasonic signals at volcanoes: Mt. Etna case study, Pure Appl. Geophys., 170, 17511771, doi:10.1007/s00024-012-0634-x.

Cavallaro, D., Cocchi, L., Coltelli, M., Muccini, F., Carmisciano, C., Firetto Carlino, M., Ibáñez, J.M., Patanè, D., Filippone, M., and E. Buttaro (2016). Acquisition procedures, processing methodologies and preliminary results of magnetic and ROV data collected during the TOMO-ETNA experiment, Annals of Geophysics, 59(4), S0431, doi:10.4401/ag-7084.

Cimini, G.B., and A. Marchetti (2006). Deep structure of peninsular Italy from seismic tomography and subcrustal seismicity, Annals of Geophysics, Supplement to vol. 49(1), 331-345.

Coltelli, M., et al. (2016). The marine activities performed within the TOMO-ETNA experiment, Annals of Geophysics, 59(4), S0428, doi:10.4401/ag-7081.

De Astis, G., Ventura, G., and G. Vilardo (2003). Geodynamic significance of the Aeolian volcanism Southern Tyrrhenian Sea, Italy, in light of structural, seismological and geochemical data, Tectonics, 22(4), 1040, doi:10.1029/2003TC001506.

De Beni, E., Behncke, B., Branca, S., Nicolosi, I., Carluccio, R., D’Ajello Caracciolo, F., and M. Chiappini (2015). The continuing story of Etna's New Southeast Crater (2012-2014): evolution and volume calculations based on field surveys and aerophotogrammetry, J. Volcanol. Geotherm. Res., 303, 175-186, dx.doi.org/10.1016/j.jvolgeores.2015.07.021.

Di Grazia, G., Falsaperla, S., and H. Langer (2006). Volcanic tremor location during the 2004 Mount Etna lava effusion, Geophys. Res. Lett., 33, L04304, doi:10.1029/2005GL025177.

Di Grazia, G., Cannata, A., Montalto, P., Patanè, D., Privitera, E., Zuccarello, L., and E. Boschi (2009). A new approach to volcano monitoring based on 4D analyses of seismo-volcanic and acoustic signals: The 2008 Mt. Etna eruption, Geophys. Res. Lett., 36, L18307, doi:10.1029/2009GL039567.

Díaz-Moreno, A., Koulakov, I., García-Yeguas, A., Jakovlev, A., Barberi, G., Cocina, O., Zuccarello, L., Scarfi, L., Patanè, D., Álvarez, I., García, L., Benítez, C., Prudencio, J., and J.M. Ibáñez (2016). PARTOS Passive and Active Ray TOmography Software: description and preliminary analysis using TOMOETNA experiment's dataset, Annals of Geophysics, 59(4), S0435, doi:10.4401/ag-7088.
Faccenna, C., Piromallo, C., Crespo-Blanc, A., Jolivet, L., and F. Rossetti (2004). Lateral slab deformation and the origin of the Western Mediterranean arcs, Tectonics, 23, TC1012, doi:10.1029/2002TC001488.

Faccenna, C., Civetta, L., D’Antonio, M., Funiciello, F., Margheriti, L., and C. Piromallo (2005). Constraints on mantle circulation around the deforming Calabrian slab, Geophys. Res. Lett., 32, doi:10.1029/2004 GL021874, ISSN: 0094-8276.

Falsaperla, S., Alparone, S., and S. Spampinato (2003). Seismic features of the June 1999 tectonic swarm in the Stromboli volcano region, Italy, J. Volcanol. Geotherm. Res., 125, 121-136.

Firetto Carlino, M., Zgur, F., Bruno, P.P.G., Coltelli, M., Sormani, L., Cavallaro, D., Ibáñez, J.M., and D. Patanè (2016). Acquisition and preliminary analysis of multi-channel seismic reflection data, acquired during the oceanographic cruises of the TOMOETNA experiment, Annals of Geophysics, 59(4), S0430, doi:10.4401/ag-7083.

Frohlich, C. (1992). Triangle diagrams: ternary graphs to display similarity and diversity of earthquake focal mechanisms, Phys. Earth Planet. In., 75(1), 193-198.

García, L., Álvarez, I., Benítez, C., Titos, M., Bueno, M., Mota, S., de la Torre, Á., Segura, J.C., Alguacil, G., Díaz-Moreno, A., Prudencio, J., García-Yeguas, A., Ibáñez, J.M., Zuccarello, L., Cocina, O., and D. Patanè (2016). Advances on the automatic estimation of the P-wave onset time, Annals of Geophysics, 59(4), S0434, doi:10.4401/ag-7087.

Giunta, G., Luzio, D., Agosta, F., Calò, M., Di Trapani, F., Giorgianni, A., Oliveri, E., Orioli, S., Perniciaro, M., Vitale, M., Chiodi, M., and G. Adelfio (2009). An integrated approach to the relationships between tectonics and seismicity in northern Sicily and southern Tyrrhenian, Tectonophysics, doi:10.1016/ j.tecto.2008.09.031.

Gruppo Analisi Dati Sismici (2016). Catalogo dei terremoti della Sicilia Orientale - Calabria Meridionale (1999-2015), INGV-Catania; http:/ / www.ct.ingv.it/ ufs / analisti / catalogolist.php.

Gueguen, E., Tavarnelli, E., Renda, P., and M. Tramutoli (2002). The geodynamics of the southern Tyrrhenian Sea margin as revealed by integrated geological, geophysical and geodetic data, Boll. Soc. Geol. It., 1, 77-85.

Hirn, A., Nercessian, A., Sapin, M., Ferrucci, F., and G. Wittlinger (1991). Seismic heterogeneity of Mt. Etna: structure and activity, Geophys. J. Int., 105, 139-153.

Ibáñez, J.M., Prudencio, J., Díaz-Moreno, A., Patanè, D., Puglisi, G., Lühr, B.-G., Carrión, F., Dañobeitia, 
J.J., Coltelli, M., Bianco, F., Del Pezzo, E., Dahm, T., Willmott, V., and V. Mazauric (2016a). The TOMOETNA experiment: an imaging active campaign at Mt. Etna volcano. Context, main objectives, working-plans and involved research projects, Annals of Geophysics, 59(4), S0426, doi:10.4401/ag-7079.

Ibáñez, J.M., et al. (2016b). TOMO-ETNA experiment at Etna volcano: activities on land, Annals of Geophysics, 59(4), S0427, doi:10.4401/ag-7080.

Mantovani, E., Albarello, D., Tamburelli, C., and D. Babbucci (1996). Evolution of the Tyrrhenian basin and surrounding regions as result of the AfricaEurasia convergence, J. Geodyn., 21, 35-37.

Martínez-Arévalo, C., Patanè, D., Rietbrock, A., and J.M. Ibáñez (2005). The intrusive process leading to the Mt. Etna 2001 flank eruption: Constrain from 3D attenuation tomography, Geophys. Res. Lett., 32, 21309-21313.

Montone, P., Mariucci, M.T., Pondrelli, S., and A. Amato (2004). An improved stress map for Italy and surrounding regions (central Mediterranean), J. Geophys. Res., 109, B10410, doi:10.1029/2003JB002703.

Musumeci, C., Scarfi, L., Palano, M., and D. Patanè (2014). Foreland segmentation along an active convergent margin: New constraints in southeastern Sicily (Italy) from seismic and geodetic observations, Tectonophysics, 630, 137-149, doi:10.1016/j.tecto. 2014.05.017.

Neri, G., Caccamo, D., Cocina, O., and A. Montalto (1996). Geodynamic implications of earthquake data in the Southern Tyrrhenian Sea, Tectonophysics, 258, 233-249.

Neri, G., Barberi, G., Orecchio, B., and A. Mostaccio (2003). Seismic strain and seismogenic stress regimes in the crust of the southern Tyrrhenian region, Earth Planet. Sc. Lett., 213, 97-112.

Norini, G., De Beni, E., Andronico, D., Polacci, M., Burton, M., and F. Zucca (2009). The 16 November 2006 flank collapse of the south-east crater at Mount Etna, Italy: study of the deposit and hazard assessment, J. Geophys. Res., 114; http://dx.doi.org/10. 1029/2008JB005779.

Patanè, D., Privitera, E., Ferrucci, F., and S. Gresta (1994). Seismic activity leading to the 1991-1993 eruption of Mt. Etna and its tectonic implications, Acta Vulcanol., 4, 47-55.

Patanè, D., Ferrucci F., Giampiccolo, E., and L. Scaramuzzino (1997). Source scaling of microearthquakes at Mt. Etna volcano and in the Calabrian Arc (southern Italy), Geophys. Res. Lett., 24, 1879-1882.

Patanè, D., and E. Giampiccolo (2004). Faulting processes and earthquake source parameters at Mount Etna: State of the Earth and perspectives, In: A. Bonac- corso, S. Calvari, M. Coltelli, C. Del Negro and S. Falsaperla (eds.), Etna Volcano Laboratory, AGU Geophysical monograph series, doi:10.1029/143GM11.

Patanè, D., Cocina, O., Falsaperla, S., Privitera, E., and S. Spampinato (2004). Mt. Etna volcano: A seismological framework, In: A. Bonaccorso, S. Calvari, M. Coltelli, C. Del Negro and S. Falsaperla (eds.), Etna Volcano Laboratory, AGU Geophysical monograph series, doi:10.1029/143GM10.

Patanè, D., Mattia, M., Di Grazia, G., Cannavò, F., Giampiccolo, E., Musumeci, C., Montalto, P. and E. Boschi (2007). Insights into the dynamical processes of the 2007 Stromboli eruption and possible meteorological influences on the magmatic system, Geophys. Res. Lett., 34, L22309, doi:10.1029/2007GL031730.

Patanè, D., Aliotta, M., Cannata, A., Cassisi, C., Coltelli, M., Di Grazia, G., Montalto, P., and L. Zuccarello (2011). Interplay between Tectonics and Mount Etna's Volcanism: Insights into the Geometry of the Plumbing System, New Frontiers in Tectonic Research - At the Midst of Plate Convergence, Uri Schattner (Ed.), ISBN: 978-953-307-594-5.

Patanè, D., Aiuppa, A., Aloisi, M., Behncke, B., Cannata, A., Coltelli, M., Di Grazia, G., Gambino, S., Gurrieri, S., Mattia, M., and G. Salerno (2013). Insights into magma and fluid transfer at Mount Etna by a multiparametric approach: A model of the events leading to the 2011 eruptive cycle, J. Geophys. Res., 118, 3519-3539, doi:10.1002/jgrb.50248.

Piromallo, C., and A. Morelli (2003). P-wave tomography of the mantle under the Alpine-Mediterranean area, J. Geophys. Res., 108, B2, doi:10.1029/2002JB 001757.

Pondrelli, S., Piromallo, C., and E. Serpelloni (2004). Convergence vs. retreat in Southern Tyrrhenian Sea: insights from kinematics, Geophys. Res. Lett., 31, L06611, doi:10.1029/2003GL019223.

Reasenberg, P.A., and D. Oppenheimer (1985). Fortran computer programs for calculating and displaying earthquake fault-plane solutions, U.S. Geol. Surv., Open File Rept., 85-379.

Richter, C.F. (1958). Elementary seismology, W.H. Freeman and Co., San Francisco, USA, 768 p.

Rizzo, A.L., Federico, C., Inguaggiato, S., Sollami, A., Tantillo, M., Vita, F., Bellomo, S., Longo, M., Grassa, F., and M. Liuzzo (2015). The 2014 effusive eruption at Stromboli volcano (Italy): Inferences from soil $\mathrm{CO}_{2}$ flux and ${ }^{3} \mathrm{He} /{ }^{4} \mathrm{He}$ ratio in thermal waters, Geophys. Res. Lett., 42, 2235-2243, doi:10.1002/2014 GL062955.

Scarfi, L., Messina, A., and C. Cassisi (2013). Sicily and southern Calabria focal mechanism database: a valuable tool for the local and regional stress field 
determination, Annals of Geophysics, 56(1), D0109, doi:10.4401/ag-6109.

Scarfi, L., Barberi, G., Musumeci, C., and D. Patanè (2016). Seismotectonics of Northeastern Sicily and Southern Calabria (Italy): New constraints on the tectonic structures featuring in a crucial sector for the Central Mediterranean geodynamics, Tectonics, 34, doi:10.1002/2015TC004022.

Selvaggi, G., and C. Chiarabba (1995). Seismicity and P-wave velocity image of the Southern Tyrrhenian subduction zone, Geophys. J. Int., 121, 818-826, doi:10.1111/j.1365-246X.1995.tb06441.x.

Sicali, S., Barberi, G., Cocina, O., Musumeci, C., and D. Patanè (2015). Volcanic unrest leading to the JulyAugust 2001 lateral eruption at Mt. Etna: Seismological constraints, J. Volcanol. Geotherm. Res., 304, 11-23, ISSN: 0377-0273.

Ventura, G., Vilardo, G., Milano, G., and N.A. Pino (1999). Relationships among crustal structure, volcanism and strike-slip tectonics in the Lipari-Vulcano volcanic complex (Aeolian Islands, Southern Tyrrhenian Sea, Italy), Phys. Earth Planet. Inter., 116, 31-52.

Vinciguerra, S., Latora, V., Bicciato, S., and R.T Kamimura (2001). Identifying and discriminating seismic patterns leading flank eruptions at Mt. Etna volcano during 1981-1996, J. Volcanol. Geotherm. Res., 106, 211-228.

Westaway, R. (1993). Quaternary uplift of Southern Italy, J. Geophys. Res., 98, 21741-21772.

Zakšek, K., Hort, M., and E. Lorenz (2015). Satellite and Ground Based Thermal Observation of the 2014 Effusive Eruption at Stromboli Volcano, Remote Sens., 7, 17190-17211, doi:10.3390/rs71215876.

Zhang, H., Thurber, C., and B. Bedrosian (2009). Joint inversion of Vp, Vs, and Vp/Vs at SAFOD, Parkfield, California, Geochem. Geophy. Geosy., 10, Q11002.

Zoback, M.L. (1992). First- and second-order patterns of stress in the lithosphere: the World Stress Map Project, J. Geophys. Res., 97(B8), 11703-11728.

Zuccarello, L., Burton, M.R., Saccorotti, G., Bean, C.J., and $\mathrm{D}$. Patanè (2013). The coupling between very long period seismic events, volcanic tremor, and degassing rates at Mount Etna volcano, J. Geophys. Res. Solid Earth, 118, doi:10.1002/jgrb.50363.

${ }^{\star}$ Corresponding author: Carla Musumeci,

Istituto Nazionale di Geofisica e Vulcanologia, Sezione di Catania,

Osservatorio Etneo, Catania, Italy; email: carla.musumeci@ingvit.

(C) 2016 by the Istituto Nazionale di Geofisica e Vulcanologia. All rights reserved. 